\title{
sciendo
}

\section{THE APPLICATIONS OF ORIGANUM VULGARE AND ITS DERIVATIVES IN HUMAN, RUMINANT AND FISH NUTRITION - A REVIEW}

\author{
Mahmoud Alagawany ${ }^{1 *}$, Mohamed E. Abd El-Hack¹, Mayada R. Farag², Hazem M. Shaheen ${ }^{3}$, \\ Mervat A. Abdel-Latif ${ }^{4}$, Ahmed E. Noreldin ${ }^{5}$, Asmaa F. Khafaga ${ }^{6}$
}

\author{
${ }^{1}$ Poultry Department, Faculty of Agriculture, Zagazig University, Zagazig 44511, Egypt \\ ${ }^{2}$ Forensic Medicine and Toxicology Department, Faculty of Veterinary Medicine, Zagazig University, \\ Zagazig 44511, Egypt \\ ${ }^{3}$ Department of Pharmacology, \\ ${ }^{4}$ Department of Nutrition and Clinical Nutrition, \\ ${ }^{5}$ Department of Histology and Cytology, Faculty of Veterinary Medicine, \\ Damanhour University, Damanhour 22516, Egypt \\ ${ }^{6}$ Department of Pathology, Faculty of Veterinary Medicine, Alexandria University, Edfina 22758, Egypt \\ •Corresponding author: mmalagwany@zu.edu.eg
}

\begin{abstract}
Origanum vulgare $\mathrm{L}$. is an aromatic enduring herb that belongs to Lamiaceae family. The bioactive constituents of this herb, such as carvacrol and thymol possess several medicinal properties, such as antioxidant, antidiabetic, anti-inflammatory, antimicrobial, antiviral, antiparasitic, antineoplastic, and immune modulatory. Moreover, it is considered a standard natural, less toxic, and residue free feed additive, that is successfully used in livestock and fish. Additionally, in human, Origanum vulgare is extensively used with promising health benefits against respiratory, digestive and urinary disorders. This review casts light on description, chemical composition and structure of Origanum vulgare, as well as its therapeutic applications in human and its biological activities in ruminants and fish, data that will be possibly useful for physiologists, nutritionists and veterinarians.
\end{abstract}

Key words: Origanum vulgare, animal, human, fish, health, antioxidant, performance, nutrition

A considerable number of sweet-smelling medicinal plants or their essential oils are already used in poultry, as a supplement into the diet or into water with positive effects on feed intake, feed conversion ratio, and carcass traits (Abd El-Hack et al., 2016, 2018; Alagawany et al., 2018; Shewita and Taha, 2018; Taha et al., 2019; Abdelnour et al, 2019). Origanum vulgare L. belongs to Lamiaceae family and it is an aromatic enduring herb found in every part of Europe. During the flowering season, the collected aerial parts contain considerable amounts of volatile oil (0.18-1.02\%) (Robu and Milica, 2004). The properties of the oregano extract result from its bioactive components that act in a synergistic manner and include diuretic, antispasmodic, 
stomachic, antimicrobial (bactericidal, fungicidal, and viricidal), antiparasitic and immunomodulator activities (Mohamed et al., 2019). In this review, chemical composition, structure, biological activities and beneficial applications of Origanum vulgare in human, ruminant and fish nutrition and health are highlighted.

\section{Description, chemical composition and structure}

Origanum vulgare L. (Lamiaceae) (O. vulgare; OV), commonly known as oregano, is an aromatic herb widely utilized around the world. O. vulgare is a spicy plant widely distributed throughout Asia, specifically in Iran. It is an evergreen herb, with 20-80 cm length, and opposite leaves of 1-4 cm length. Its flower has a purple color, 3-4 mm length, and bears erect spikes. This plant is sometimes mistakenly named wild marjoram, as it is closely related to O. majorana. Oregano is implanted in early spring, the plants being distributed $30 \mathrm{~cm}$ (12 in) apart in clearly dry soil, with full sun. Oregano is developed in a $\mathrm{pH}$ limit between 6.0 and 9.0, with a favored range between 6.0 and 8.0 (Peter, 2004).

The antimicrobial activity of $O$. vulgare is a result of its high content in volatile oils (Esen et al., 2007; Karakaya et al., 2011). In addition, these volatile constituents significantly contribute to the aroma and flavour of the herb. The phenolic compounds including flavonoids and phenolic acids are responsible for its antioxidant activity (Chou et al., 2010; Liang et al., 2012; Arif et al., 2019). Moreover, these phenolic antioxidants possess diverse biological activities, for instance, anti-ulcer, antiinflammatory, antidiabetic, antiviral, cytotoxic and anti-tumor (Saxena et al., 2012), and they are strongly associated with the health effects of Origanum vulgare. Six new phenolic compounds (1-6) from Origanum vulgare, could be isolated along with five known ones: 2,5-dihydroxybenzoic acid (7) (Xie and Li, 2002), 3,4-dihydroxybenzoic acid (8) (Zhang et al., 2008), rosmarinic acid (9) (Wu et al., 2011), origanoside (10) (Nakatani and Kikuzaki, 1987), and maltol 60-O-(5-O-p-coumaroyl)-b-D-apiofuranosyl-b-Dglucopyranoside (11) (Li et al., 2008). The structures of the new compounds were identified with spectroscopic analyses and acid hydrolysis experiments. The phenolic compounds combine with the previously isolated ones E-caffeic acid (12), amburoside A (13), oresbiusin A (14), (+)-(R)-butyl rosmarinate (15), apigenin (16), apigenin 7-O-b-D-glucoside (17), luteolin (18), 6,7,40-trihydroxyflavone (19), 5,7,30,40-tetrahydroxy-8-C-p-hydroxybenzylflavone (20) and didymin (21) (Guo et al., 2012).

\section{Therapeutic uses of oregano in human}

In the last decades, there is a great necessity to search for medicinal plants and herbs as an alternative source of antioxidants. Natural products that are extracted from medicinal plants and fruits possess substantial antioxidant properties. As a result, they can be utilized for the development of novel drugs (Newman and Cragg, 2007). Oregano is a worldwide herb that is extensively used due to its medicinal activities against respiratory, digestive and urinary disorders in addition to dental caries and rheumatoid arthritis (Liang and Lu, 2012). It is utilized to restore respiratory health and relieve a disturbing situation due to abnormal blood glucose levels or leukemia (Sheibani et al., 2010). Moreover, Chou et al. (2010) have described the 
antioxidant properties of the plant. The aforementioned pharmacological properties of Origanum vulgare are attributed to its high content in carvacrol and other phenolic compounds (Suntres et al., 2015).

\section{Anticarcinogenic activity}

The medicinal plants have dietary phenolic phytochemicals which are a rich source of antioxidants (Dhama et al., 2018; Alagawany et al., 2019; Farag and Alagawany, 2019; Khafaga and Bayad 2016 a, b). These phenolic substances have advantageous outcomes on human health, in particular by preventing mutagenesis along with carcinogenesis. Radiation and chemotherapeutic treatment are the standard available approach in treatment of malignant tumors (Abd El-Hack et al., 2019). However severe side effects were associated with such treatments. Therefore, the alternative medicinal plants which possess antimicrobial effects and associated anticarcinogenic actions may provide accepted solution, as stated by Al-Kalaldeh et al. (2010) who analyzed and investigated the basic oils of Laurus nobilis L., Origanum syriacum L., Origanum vulgare L., and Salvia triloba L. using gas chromatographymass spectrometry for their antiproliferative activity against breast adenocarcinoma (MCF7). The major constituent of $O$. vulgare was trans-sabinene hydrate $(27.19 \%)$. The ethanol plant extracts of $O$. triloba exhibited an antiproliferative activity against MCF7 as shown by the IC50 values of $6.40,24.49$, and $25.25 \mu \mathrm{g} / \mathrm{mL}$. In contrast, none of the essential oils or aqueous extracts of the tested plant species showed a cytotoxic activity. Recent studies showed that dietary supplementation with O. vulgare may protect against DNA damage in blood lymphocytes and lipid peroxidation resulted from internal radiation and several insults (Salimei et al., 2007; Arami et al., 2013). In a study conducted by Arami et al. (2013), the radio-protective effects of Origanum vulgare extract $(12.5,25,50$ and $100 \mathrm{lg} / \mathrm{mL})$ toward the genotoxic outcomes in human lymphocytes caused by radioiodine (131I) were examined. The three higher doses markedly dropped the micronuclei incidence in refined human lymphocytes with the greatest protective effect at $100 \mathrm{lg} / \mathrm{mL}$, which cause a reduction of $70 \%$. The protection against DNA damage is considered a great evidence of the antioxidant capacity of the plant, because oregano contains a considerable level of phenolic metabolites as carvacrol and thymol that possess antioxidant properties. Additionally, carvacrol blocks the spreading of human ovarian adenocarcinoma cells, beside tumor cells resistant to adriamycin, vincristine, and cisplatin (Ait M'barek et al., 2007) but limited data concerning the mode of action related with its chemopreventive effects are available. Also, oregano aqueous extract was used to synthesize silver nanoparticles by reducing $1 \mathrm{mM}$ silver nitrate $\left(\mathrm{AgNO}_{3}\right)$ solution. The acquired nanoparticles were substantial $(-26 \pm 0.77 \mathrm{mV})$ at surrounding temperature. These green synthesized nanoparticles were recognized to be effective in restraining important human pathogens. In addition, these silver nanoparticles displayed a dose dependent manner response toward human lung cancer A549 cell line (LD50 - $100 \mathrm{~g} / \mathrm{ml}$ ) (Sankar et al., 2013).

Colon cancer is a principal factor of mortality in developed countries. Dietary supplementation with the aqueous extract of Origanum vulgare was suggested to provide protection against colon cancer. Srihari et al. (2008) observed the impact of 
Origanum vulgare at the levels of 20, 40 and 60 ppm on lipid peroxidation activities in a 1,2-dimethylhydrazine (DMH)-motivated rat colon carcinogenesis model. Postmortem and biochemical colon examination of colon cancer-suffered rats showed that continuous dietary oregano supplement $(40 \mathrm{ppm})$ has influence on tissue lipid peroxidation profiles. As the data was limited about the anticarcinogenic effect of oregano, Savini et al. (2009) continued the investigation on the role of oregano in lowering the risk of colon cancer. They found that oregano offers a pro-apoptotic effect, which may be selective for cancer cells. Additionally, entire extract, in place of a distinctive constituent, can be accountable for the attributed cytotoxic effects. The beneficial effects of oregano essential oil (OEO) determined to its prominent carvacrol content were extended to involve the protection against skin lesions. OEO induced marked antiproliferative effects in human dermal fibroblasts and significantly inhibited several inflammatory biomarkers (Han and Parker, 2017).

Kubatka et al. (2017) investigated the anti-cancer effects of lyophilized oregano in an in vitro and in vivo breast cancer mice model which showed suppression of tumor frequency by $55.5 \%$, tumor volume by $44.5 \%$, and tumor incidence by $44 \%$ compared to control animals. The results revealed a significant lowering in the rate of poorly differentiated (high grade, HG) and well-differentiated (low grade, LG) mammary carcinomas.

\section{Antimicrobial activity}

In a study carried out by Chun et al. (2005), the antimicrobial properties of oregano phenolic extracts against ulcer-involved Helicobacter pylori using standard agar diffusion method were investigated. The variations in physical and chemical characters of phenolic acids contents were suggested to participate in growth suppression of H. pylori. Recently, Sankar et al. (2013) conducted a study with an aqueous extract of oregano in the production of silver nanoparticles which were found to carry an advanced antibacterial activity toward several human pathogenic bacterial species with respect to Chloramphenicol. In addition, Origanum vulgare L. can be utilized as organic alternative antimicrobial for food storage. Therefore, O. vulgare basic oil was capable to suppress the development of some food-involved Aspergillus species (A. niger, A. fumigatus, A. ochraceus, A. terreus A. parasiticus, and A. flavus). $O$. vulgare basic oil showed a minimum inhibition concentration (MIC50) at $40 \mu \mathrm{L} / \mathrm{mL}$. Intense fungicidal effects against $A$. flavus, A. fumigatus and A. niger were found at 40 and $80 \mu \mathrm{L} / \mathrm{mL}$ by inhibiting the mycelial development which support the possibility of using $O$. vulgare oil as an anti-fungal compound for food preservation (Carmo et al., 2008). In an experiment conducted by Adams et al. (2011), the in vitro antifungal activities of Oregano basic oil against four human pathogenic yeasts (Candida albicans, Cryptococcus albidus, Cryptococcus neoformans and Rhodotorula rubrum) were examined. Oregano basic oil at the level of $200 \mu \mathrm{g} / \mathrm{mL}$ was recognized as a growth inhibiting agent against all the examined four yeasts. Similarly, several studies supported the antimicrobial activity of Oregano oil against various types of pathogenic fungi such as Bacillus subtilis, Candida albicans, Enterobacter cloacae, Escherichia coli, Mycobacterium avium, Pseudomonas aeruginosa, Salmonella typhimurium, Staphylococcus aureus, Aspergillus flavus, Listeria monocytogenes, 
and Salmonella enteritidis (Hammer et al., 1999; Soković et al., 2010; Bajpai et al., 2012; Krishan and Narang, 2014). The minimum inhibitory concentrations (MIC) of oregano essential oil against pathogenic microorganisms in vitro are summarized in Table 1. Coccimiglio et al. (2016) suggested that the observed antimicrobial activities of oregano against Gram-negative and Gram-positive bacterial strains are mainly attributed to carvacrol and thymol content. Pensel et al. (2014) suggested that the basic oils contained in $T$. vulgaris and $O$. vulgare have outstanding anthelmintic effects against protoscoleces and E. granulosus cysts. Manohar et al. (2001) detected the absence of fungi from the Candida albicans infected kidney after the effective treatment with $8.6 \mathrm{mg}$ of oregano oil in $100 \mu \mathrm{l}$ of olive oil $/ \mathrm{kg}$ body weight.

Table 1. Minimum inhibitory concentrations (MIC) of oregano essential oil main components against pathogenic microorganisms in vitro

\begin{tabular}{|c|c|c|c|}
\hline References & $\begin{array}{c}\text { In vitro } \mathrm{MIC}\left(\mu \mathrm{g} \mathrm{ml}^{-1}\right) \\
\text { data }\end{array}$ & Species of microorganism & Components \\
\hline $\begin{array}{l}\text { Bajpai et al., 2012; } \\
\text { Krishan and Narang, 2014; } \\
\text { Soković et al., 2010; } \\
\text { Alagawany et al., } 2020\end{array}$ & $\begin{array}{c}0.125 \\
113.0-200.0 \\
0.5 \\
0.5-225.0 \\
72.0 \\
1.0 \\
0.25-0.5 \\
0.25-450.0\end{array}$ & $\begin{array}{l}\text { Bacillus subtilis } \\
\text { Candida albicans } \\
\text { Enterobacter cloacae } \\
\text { Escherichia coli } \\
\text { Mycobacterium avium } \\
\text { Pseudomonas aeruginosa } \\
\text { Salmonella typhimurium } \\
\text { Staphylococcus aureus }\end{array}$ & Carvacrol \\
\hline Kurekci et al., 2013 & 0.05 & Campylobacter jejuni & Terpinen-4-ol \\
\hline $\begin{array}{l}\text { Bajpai et al., 2012; } \\
\text { Krishan and Narang, 2014; } \\
\text { Soković et al., } 2010\end{array}$ & $\begin{array}{c}0.25 \\
1.0 \\
1.0-450.0 \\
1.5 \\
0.05-56.0 \\
0.25-225.0\end{array}$ & $\begin{array}{l}\text { Bacillus subtilis } \\
\text { Enterobacter cloacae } \\
\text { Escherichia coli } \\
\text { Pseudomonas aeruginosa } \\
\text { Salmonella typhimurium } \\
\text { Staphylococcus aureus }\end{array}$ & Thymol \\
\hline $\begin{array}{l}\text { Bajpai et al., 2012; } \\
\text { Esper et al., 2014; } \\
\text { Hammer et al., 1999; } \\
\text { Hulánková and Bořilová, 2012; } \\
\text { Hyldgaard et al., 2012; } \\
\text { Roofchaee et al., 2011; } \\
\text { Soković et al., 2010; } \\
\text { Tongnuanchan and Benjakul, } \\
2014\end{array}$ & $\begin{array}{c}10.0 \\
0.125 \\
10-20 \\
0.5 \\
0.5-1.2 \\
0.2-2.36 \\
0.5 \\
0.1-3.1 \\
0.25-3.2\end{array}$ & $\begin{array}{l}\text { Aspergillus flavus } \\
\text { Bacillus subtilis } \\
\text { Candida albicans } \\
\text { Enterobacter cloacae } \\
\text { Escherichia coli } \\
\text { Listeria monocytogenes } \\
\text { Salmonella enteritidis } \\
\text { Salmonella typhimurium } \\
\text { Staphylococcus aureus }\end{array}$ & $\begin{array}{l}\text { Carvacrol } \\
\text { Cymene } \\
\text { Thymol }\end{array}$ \\
\hline Adams et al., 2011 & 200 & $\begin{array}{l}\text { Candida albicans } \\
\text { Cryptococcus albidus } \\
\text { Cryptococcus neoformans } \\
\text { Rhodotorula rubrum }\end{array}$ & $\begin{array}{l}\text { Oregano basic } \\
\text { oil }\end{array}$ \\
\hline
\end{tabular}

\section{Antioxidant activities}

Oregano is commonly used as safe feed additive containing massive phenolic contents with antioxidative characters. Additionally, O. vulgare could protect against lung injury and hepatic toxicity. Habibi et al. (2015 a) assessed the effects of $O$. vul- 
gare at 50,100, 200, and $400 \mathrm{mg} / \mathrm{kg}$ against the liver toxicity caused by Cyclophosphamide $(200 \mathrm{mg} / \mathrm{kg}$ intraperitoneal route) in mice. Pretreatment with $O$. vulgare $(400 \mathrm{mg} / \mathrm{kg}$ ) clearly restored the serum hepatic markers (ALP, ALT and ALT), a fact that was subsequently confirmed by histological examination of liver tissues showing hepatoprotective effect of oregano. Similarly, its protective role against lung injury also induced by cyclophosphamide injection in mice was assessed by Shokrzadeh et al. (2014). Moreover, Şen et al. (2014) found out that pretreatment with carvacrol and pomegranate extract mixture could counteract the methotrexate-caused lung injury in a rat model. Carvacrol and pomegranate extract exerted their beneficial effects by improving antioxidant defense, while decreasing malondialdehyde, total oxidant state, and oxidative stress index in lung tissues and cardiac blood samples.

By using the colitis induced mice model, Bukovská et al. (2007) observed the anti-inflammatory influences of the combination of oregano and thyme essential oil, administered at the levels of $0.2 \%$ and $0.1 \%$, respectively. The authors detected a marked improvement in the histological architecture of the colon. The excessive doses of particular component can lead to adverse effect, but Llana-Ruiz-Cabello et al. (2017) proved the lack of toxicity from oregano supplementation even in 330-fold higher doses than normal consumption. Soliman et al. (2016) observed the improvement of dyslipidemia in diabetic rat as an effect of normal renal histology restoration, decrease of lipids accumulation and increase of liver parenchyma regeneration after oregano administration. Mohamed (2017) reported that oregano oil, via its antioxidant properties, has a significant protective effect on testis and spleen tissues against the toxicity of mercuric chloride. Vujicic et al. (2016) studied the therapeutic properties of ethyl extract of Origanum vulgare against Streptozotocin-induced diabetes in mice and interestingly, the authors observed a preservation of the pancreatic islets morphology lowering of proinflammatory macrophage/Th1/Th17 levels as a response to Origanum vulgare. The protective activity of Origanum vulgare against the carbon tetra chloride induced hepatotoxicity was reported by Sikander et al. (2013). Moghaddam et al. (2013) detected a partial decrease of the glomular expansion and oxidative stress in kidney of diabetic mice by prolonged treatment of Origanum majorana. Moreover, Habibi et al. (2015 b) studied the protective effects of Origanum vulgare against the hepatotoxicity caused by cyclophosphamide in mice. The authors detected a satisfactory preservation of the hepatic architecture by observing the normal sinusoidal space, normal central vein, small portal space with mild lymphocytic infiltration, and nearly normal hepatocytes. Sankar et al. (2014) developed titanium dioxide nanoparticles from Origanum vulgare and used it in wound treatment. They reported a marked wound healing by titanium dioxide nanoparticles of Origanum vulgare. Al-Kushi (2014) studied the influence of aqueous extract of Origanum vulgare on the embryos during the pregnancy of rabbit and the author confirmed that the use of Origanum vulgare during pregnancy can be perceived as safe. Moreover, it was reported that oregano oil can improve uterus, ovaries and pituitary histological architecture in rabbits infected vaginally by Candida albicans (Hasan et al., 2016). Vujicic et al. (2015) detected a significant reduction of diabetic incidence after the application of a methanolic extract of Origanum vulgare in contrast to the aqueous 
extract that had no effect. The authors attributed their results to the attenuation of pro-inflammatory response mediated by $\mathrm{T}$ helper 17 cells, and the enhancement of anti-inflammatory response mediated by $\mathrm{T}$ helper 2 and $\mathrm{T}$ regulatory cells and the preservation of b-cells from in vitro apoptosis.

\section{Biological activities in ruminants}

\section{Rumen fermentation, nutrient digestibility and production}

Essential oils appeared to regulate methane emissions and protein downfall in either in vitro or in vivo studies in ruminants (Abd El-Hack et al., 2016). Prospective studies should be organized with the intention to identify the beneficial oregano compounds and to standardize oregano doses. On-farm trials are necessary to examine their effects on animal health status, growth performance and economic efficiency (Cobellis et al., 2016). In a dose-dependent manner, a broad variety of essential oils (derived from garlic, thyme, oregano, cinnamon, etc.) has been recognized to reduce methane emissions in vitro. But at high levels, the drop in methanogenesis was induced by opposing effects against fermentation process as drop in feed digestibility or volatile fatty acids production (Sejian et al., 2015). Carvacrol which is the major constituent of oregano is effective as methane inhibitor in addition to lowering of acetate, propionate and total volatile fatty acids concentrations as stated by Benchaar and Greathead (2011), and Patra (2011).

In the rumen, acetate and butyrate are produced by Gram positive bacteria, while Gram negative bacteria generally produce propionate (Watanabe et al., 2010; Ayudthaya et al., 2018). Oregano oil and carvacrol could inhibit several strains of pathogenic bacteria. Thymol is also an effective methane inhibitor due to the suppression of Methanobrevibacter smithii which occurred only at the level of 1,000 ppm of the commercial combination of basic oils, obtained from Cinnamomum verum, Origanum vulgare, Anethum graveolens and Thymus vulgaris, while the lower levels $(5,10,20,40,80$, and $160 \mathrm{ppm})$ did not have an effect on the propagation of Methanobrevibacter smithii (Bhatta, 2015; Soren et al., 2015). Additionally, Tekippe et al. (2011) discovered that an oregano feed supplement added to ruminants total mixed ration at the level of $500 \mathrm{~g} /$ day could inhibit methane production $8 \mathrm{~h}$ post feeding. On the other hand, it had no effect on rumen $\mathrm{pH}$, volatile fatty acids profile, microbial protein outflow, microbial profiles, dry matter intake, and apparent total tract digestibly of nutrients. Moreover, average milk yield and chemical composition (protein, lactose, and urea nitrogen concentrations) were not affected by oregano supplementation but milk fat concentration, feed and milk net energy for lactation efficiencies were increased beside an increase of $3.5 \%$ in fat milk yield without affecting the main components of milk and its sensory attributes in dairy cows (Lacerda et al., 2014). In addition, oregano dietary supplementation could increase the antioxidant capacity of milk in goats (Paraskevakis, 2015).

Kolling et al. (2016) investigated the impact of Oregano extract (OE) feed additive in dairy heifers on physiological profile, feeding behavior, and performance. They found no clear statistical differences among treatments for total dry matter intake (DMI), but DMI was 9\% lower for heifers that received OE at the level of $7.5 \mathrm{~g} /$ heifer/day when compared to control or those that received OE at the level of 
$2.5 \mathrm{~g} /$ heifer/day. The addition of $7.5 \mathrm{~g} /$ day/heifer of Oregano extract caused negative impacts in feeding activity and concentrate intake, without a significant effect on total dry matter intake. Similarly, Hristov et al. (2013) reported that leaf material of Origanum vulgare L. utilized at the levels of 250-750 g/d dropped rumen methane emissions in dairy cows for $8 \mathrm{~h}$ after feeding. In addition, dry matter intake was decreased, without milk fatty acid composition changes. Oh and Hristov (2016) continued their work to detect that dietary supplementation with oregano leaves $(750 \mathrm{~g} / \mathrm{d} ; 1.05 \mathrm{~g} / \mathrm{kg}$ live body weight) containing carvacrol and thymol in dairy cows decreased the proportion of Ruminococcus flavefaciens, which is one of the major rumen fibrolytic species. In in vivo studies, inclusion of oregano leaves in the diet of lactating dairy cows did not affect ruminal $\mathrm{pH}$ and volatile fatty acids concentrations. Yadeghari et al. (2013) demonstrated that Origanum vulgare affected ruminal fermentation according to its dose and the type of substrate.

Paraskevakis (2017) reported that a long-term dietary supplementation with dried oregano (Origanum vulgare ssp. hirtum) (20 g of dried oregano plants to provide daily dosage of $1 \mathrm{ml}$ of essential oil (EO) per animal) increased the protease activity and ammonia concentration in the rumen. Also, Peptostreptococcus anaerobius, and Clostridium sticklandii were found to be the most sensitive to oregano at the current dosage. Furthermore, the total methanogen population was significantly decreased. Acetate percentage was decreased in high fiber diet, but showed an increasing pattern in medium fiber diet, and low fiber diet following addition of oregano and thyme oils. Propionate levels exhibited a decline in majority of the treatment combinations. However, butyrate levels witnessed significant increase compared to control diets.

Chaudhary et al. (2016) used qRT-PCR to analyze the ruminal microbes after supplementation of thyme and oregano oil; they reported significant reduction in methanogen and fungal counts following addition of thyme oil. However, significant up-regulations of methanogen counts and reduction of fungal counts were observed with supplementation of oregano oil. Research was extended in Merino lambs, where Biricik et al. (2016) stated that when lambs were fed diets supplemented with thymol and/or carvacrol additives at the doses of 100 and 300 ppm, a higher rumen $\mathrm{pH}$, ammonia levels and total volatile fatty acids were observed compared to those of the animals in the control group. However, supplementation did not alter feed conversion ratio or molar concentration of total volatile fatty acid. At the same time, carcass weight and traits were similar among all the groups.

\section{Antiparasitic activities}

The inclusion of a preparation containing the essential oil blend of $O$. vulgare and Citrus spp. in the diet of sheep resulted in a decrease of both the intensity and prevalence of coccidian infection within the flock and in an increase of lamb growth performance (Dudko et al., 2017). Also, the essential oil of O. onites L. is effective in controlling tick infections (Coskun et al., 2008). On this basis, Tabari et al. (2017) evaluated the repel potency, ovicidal and larvicidal impacts of $O$. onites L. compounds against $I$. ricinus. Carvacrol and thymol at the majority of the tested concentrations showed $>90 \%$ repel property on I. ricinus. Linalool was partially ef- 
fective (50.24\% repel potency) only at the concentration of 5\%. Generally, based on these results, carvacrol and thymol can be expected as prospective compounds for the improvement of innovative acaricidal preparations to control the propagation of I. ricinus and associated tick-borne diseases.

\section{Antibacterial activities}

Cho et al. (2015) conducted an experiment to examine whether oregano essential oil could substitute antibiotics (gentamycin) for the control of subclinical bovine mastitis caused by $S$. aureus and/or E. coli. As indicated by the decreased number of these microbes in milk in addition to low white blood cell counts, oregano essential oil could serve as a feasible alternative to antibiotics. Furthermore, daily administration of oregano essential oil (Origanum vulgare ssp. hirtum) (ECODIAR ${ }^{\circledR}$ liquid $5 \%$ ) at the dose of $12.5 \mathrm{mg} / \mathrm{kg}$ body weight once daily in calves for the first 10 days of their life effectively diminishes the severity of naturally acquired diarrhea under field conditions and, under certain hygiene practices, possesses a preventive effect against neonatal diarrhea syndrome (Katsoulos et al., 2017). In addition, Bampidis et al. (2006) detected the good impact of dried oregano leaves on the treatment of diarrhea caused by Escherichia coli in calves. The main findings associated to the supplementation of oregano essential oil in ruminants are presented in Table 2.

Table 2. The main findings associated to the supplementation of oregano essential oil for ruminant

\begin{tabular}{|c|c|c|c|}
\hline References & Main findings & $\begin{array}{l}\text { Studied } \\
\text { species }\end{array}$ & $\begin{array}{l}\text { Components of } \\
\text { oregano basic oil }\end{array}$ \\
\hline 1 & 2 & 3 & 4 \\
\hline $\begin{array}{l}\text { Tekippe et al., } 2011 \\
\text { Lacerda et al., } 2014\end{array}$ & $\begin{array}{l}\text { Inhibit methane production } 8 \mathrm{~h} \text { post } \\
\text { feeding } \\
\text { No effect on rumen } \mathrm{pH} \text {, volatile fatty } \\
\text { acids profile, microbial protein outflow, } \\
\text { microbial profiles, dry matter intake, and } \\
\text { apparent total tract digestibly of nutri- } \\
\text { ents, average milk yield and chemical } \\
\text { composition } \\
\text { Milk fat concentration, feed and milk } \\
\text { net energy for lactation efficiencies were } \\
\text { increased } \\
\text { Increase of } 3.5 \% \text { in fat milk yield }\end{array}$ & Ruminants & $\begin{array}{l}\text { Oregano feed } \\
\text { supplement } \\
(500 \mathrm{~g} / \mathrm{d})\end{array}$ \\
\hline Kolling et al., 2016 & $\begin{array}{l}\text { Dry matter intake was } 9 \% \text { lower com- } \\
\text { pared to control } \\
\text { Negative impacts on feeding activity and } \\
\text { concentrate intake }\end{array}$ & Dairy heifers & $\begin{array}{l}\text { Oregano extract } \\
(7.5 \mathrm{~g} / \mathrm{heifer} / \mathrm{d})\end{array}$ \\
\hline Hristov et al., 2013 & $\begin{array}{l}\text { Decreased rumen methane emissions in } \\
\text { dairy cows for } 8 \mathrm{~h} \text { after feeding } \\
\text { Dry matter intake was decreased } \\
\text { Milk fatty acid composition did not } \\
\text { change }\end{array}$ & Dairy cows & $\begin{array}{l}\text { Leaf material of } \\
\text { Origanum vulgare } \\
\text { L. }(250-750 \mathrm{~g} / \mathrm{d})\end{array}$ \\
\hline Oh and Hristov, 2016 & $\begin{array}{l}\text { Decreased proportion of Ruminococcus } \\
\text { flavefaciens }\end{array}$ & Dairy cows & $\begin{array}{l}\text { Oregano leaves } \\
(750 \mathrm{~g} / \mathrm{d} \text {; } \\
1.05 \mathrm{~g} / \mathrm{kg} \text { bwt })\end{array}$ \\
\hline
\end{tabular}


Table 2 - contd.

\begin{tabular}{|c|c|c|c|}
\hline 1 & 2 & 3 & 4 \\
\hline Paraskevakis, 2017 & $\begin{array}{l}\text { Increased the protease activity and am- } \\
\text { monia concentration in the rumen } \\
\text { Peptostreptococcus anaerobius, and } \\
\text { Clostridium sticklandii were most sensi- } \\
\text { tive to oregano } \\
\text { The total methanogen population was } \\
\text { significantly decreased } \\
\text { Acetate percentage was decreased in } \\
\text { high fiber diet, and increased in medium } \\
\text { and low fiber diet } \\
\text { Decreased propionate levels } \\
\text { Increased butyrate levels }\end{array}$ & Goat & $\begin{array}{l}\text { Oregano }(20 \mathrm{~g} \text { of } \\
\text { thyme and oregano } \\
\text { oil) }\end{array}$ \\
\hline Chaudhary et al., 2016 & $\begin{array}{l}\text { Significant reduction in methanogen and } \\
\text { fungal counts with supplementation of } \\
\text { thyme oil } \\
\text { Significant increase of methanogen } \\
\text { counts and reduction of fungal counts } \\
\text { with supplementation of oregano oil }\end{array}$ & $\begin{array}{l}\text { Ruminal } \\
\text { microbial } \\
\text { population } \\
\text { (in vitro study) }\end{array}$ & $\begin{array}{l}\text { Thyme and regano } \\
\text { oil }\end{array}$ \\
\hline Biricik et al., 2016 & $\begin{array}{l}\text { Increased rumen } \mathrm{pH} \text {, ammonia levels } \\
\text { and total volatile fatty acids } \\
\text { No alteration in feed conversion ratio, } \\
\text { molar concentration of total volatile fatty } \\
\text { acid and carcass weight }\end{array}$ & Merino lambs & $\begin{array}{l}\text { Thymol and } \\
\text { carvacrol additives } \\
\text { at the doses of } 100 \\
\text { and } 300 \mathrm{ppm} \mathrm{s} \text {. }\end{array}$ \\
\hline Dudko et al., 2017 & $\begin{array}{l}\text { Decrease of both the intensity and preva- } \\
\text { lence of coccidian infection } \\
\text { Increased lamb growth performance }\end{array}$ & Sheep & $\begin{array}{l}\text { Oil blend of } O \text {. } \\
\text { vulgare and Citrus } \\
\text { spp. }\end{array}$ \\
\hline Tabari et al., 2017 & $\begin{array}{l}\text { More than } 90 \% \text { repel property against } \\
\text { I. ricinus }\end{array}$ & & $\begin{array}{l}\text { Carvacrol and } \\
\text { thymol }\end{array}$ \\
\hline Cho et al., 2015 & $\begin{array}{l}\text { Decreased number of microbes in milk } \\
\text { Low white blood cell counts }\end{array}$ & Bovine & $\begin{array}{l}\text { Oregano essential } \\
\text { oil }\end{array}$ \\
\hline Katsoulos et al., 2017 & $\begin{array}{l}\text { Decrease the severity of naturally } \\
\text { acquired diarrhea and neonatal diarrhea } \\
\text { syndrome }\end{array}$ & Calves & $\begin{array}{l}\text { Oregano essential } \\
\text { oil }(12.5 \mathrm{mg} / \mathrm{kg} \\
\text { bwt) }\end{array}$ \\
\hline
\end{tabular}

\section{Biological activities in fish}

Ferreira et al. (2016) studied the effect of the oregano oil on the hepatic and intestinal morphometry of the Yellow Tail Tetra fish. Interestingly, a significant positive effect of the oregano oil on the increasing absorptive area of the intestine was found. Moreover, authors observed a great deposition of glycogen in the hepatocytes as an effect of oregano oil. In another investigation conducted by Ziari et al. (2015), an acceleration of oocyte maturation and an increase of oocyte diameter in the Trichogaster trichopterus fish were observed as an effect of Origanum vulgare stimulation (greater than that of LHRH-A2). Yigit et al. (2017) detected an adverse influence of prolonged use of oregano oil on the liver and kidney of rainbow trout represented by hepatocyte cytoplasmic vacuolation and renal necrotic changes in tubule epithelial cells. 
Rafieepour et al. (2020) evaluated the effect of Origanum vulgare extract on immune responses and hematological parameters of rainbow trout (Oncorhynchus mykiss). Six hundred rainbow trout (Oncorhynchus mykiss) with an average mean weight of $13 \pm 0.05 \mathrm{~g}$ were randomly allocated into two groups including placebotreated group (control), and Origanum vulgare extract-treated group (1\%), each of three replicates. The fishes were hand-fed once a day with the experimental diets for 8 weeks. At the end of every two weeks $24 \mathrm{~h}$ after feeding, fish were bled from caudal vein and blood samples were analyzed for some of hematological and immunological parameters. The results showed that serum total protein, albumin and globulin, respiratory burst activity, phagocytic activity and serum lysozyme activity were found to be higher in OE-treated group $(\mathrm{P}<0.05)$. It was concluded that supplementation with $\mathrm{OE}$ at a rate of $1 \%$ induced higher immunological responses. Therefore, dietary inclusion with $\mathrm{OE}$ could improve nonspecific immune responses in rainbow trout. Future studies to determine optimal herb mixtures and dietary levels should be conducted.

Rafieepour et al. (2020) carried out a study to evaluate the ameliorating properties of oregano (Origanum vulgare) (ORG) extract against the toxic effects of organophosphate pesticide, diazinon on growth and some metabolism associated components of rainbow trout (Oncorhynchus mykiss). In non-diazinon-exposed fish, the triiodothyronine (T3) levels in serum and body weight index (BWI \%) and specific growth rate (SGR) values were higher in fish supplemented with 2, 6 and $10 \mathrm{~g}$ $\mathrm{ORG} / \mathrm{kg}$ diet compared to control (non-ORG-supplemented fish) and fish fed $14 \mathrm{~g}$ $\mathrm{ORG} / \mathrm{kg}$ diet after 60 days feeding trial $(\mathrm{P}<0.05)$. Furthermore, the serum thyroxine (T4) levels increased in fish fed 6 and $10 \mathrm{~g}$ ORG/kg diet compared to control and those supplemented with 2 and $14 \mathrm{~g} \mathrm{ORG/kg} \operatorname{diet}(\mathrm{P}<0.05)$. Fish supplemented with $14 \mathrm{~g} / \mathrm{kg}$ ORG diet showed the lowest BWI \%, SGR and serum thyroid hormones $(\mathrm{P}<0.05)$. The lowest FCR values were observed in fish supplemented with 6 and $10 \mathrm{~g} \mathrm{ORG} / \mathrm{kg} \operatorname{diet}(\mathrm{P}<0.05)$. In diazinon exposed fish, thyroid hormones, BWI \% and SGR significantly declined during 60-day exposure to diazinon in control and ORGsupplemented fish $(\mathrm{P}<0.05)$. However, these parameters were found to be higher in fish supplemented with 6 and $10 \mathrm{~g} \mathrm{ORG/kg} \mathrm{diet} \mathrm{compared} \mathrm{to} \mathrm{other} \mathrm{exposed} \mathrm{fish}(\mathrm{P}<0.05)$. FCR values significantly increased in control and fish supplemented with 2, 6 and $14 \mathrm{~g}$ $\mathrm{ORG} / \mathrm{kg}$ diet after exposure $(\mathrm{P}<0.05)$. The levels of cortisol were significantly elevated during exposure to diazinon in control and fish supplemented with 2 and $14 \mathrm{~g} \mathrm{ORG} / \mathrm{kg}$ diet $(\mathrm{P}<0.05)$. The glucose levels significantly increased in fish fed 6 and $10 \mathrm{~g} \mathrm{ORG} /$ $\mathrm{kg}$ diet $(\mathrm{P}<0.5)$. During exposure period, diazinon induced ranges of histological lesions in liver, and the severity of theses lesions was lower in ORG-supplemented fish $(\mathrm{P}<0.05)$. In conclusion, $\mathrm{ORG}$ at optimum dietary levels $(6-10 \mathrm{~g} / \mathrm{kg}$ diet $)$ could moderate the growth suppressing effects, stress and tissue lesions induced by diazinon. In addition, ORG at high dietary levels had toxic effects on fish metabolism.

Rafieepour et al. (2019) investigated the moderating effects of oregano extract (Origanum vulgare L.) on oxidative stress and toxicity induced by organophosphate pesticide, diazinon $(0.287 \mathrm{mg} / \mathrm{l})$ in rainbow trout (Oncorhynchus mykiss) by measuring antioxidant and metabolic enzymes. In non-diazinon-exposed fish, the hepatic levels of total antioxidant capacity (TAC) and antioxidant enzymes including super- 
oxide dismutase (SOD), catalase (CAT), and glutathione peroxidase (GPX) were elevated in fish supplemented with 6 and $10 \mathrm{~g}$ ORG $/ \mathrm{kg}$ diet compared to control group (non-ORG-supplemented fish). The supplementation of fish with $14 \mathrm{~g} \mathrm{ORG/kg} \mathrm{diet}$ significantly decreased the hepatic antioxidant enzymes compared to control. The acetylcholinesterase (AChE) activity and malondialdehyde (MDA) levels remained unchanged in all groups throughout the experiment. The serum levels of hepatic metabolic enzymes [(aspartate aminotransferase (AST), alanine aminotransferase (ALT), and lactate dehydrogenase (LHD)] remained unchanged in all experimental groups throughout the experiment. In diazinon-exposed groups, the activity of SOD, GPx, and TAC in liver was elevated after exposure to diazinon in fish fed 2, 6, and $10 \mathrm{~g} \mathrm{ORG} / \mathrm{kg}$ diet. The CAT activity increased only in fish supplemented with 6 and $10 \mathrm{~g} \mathrm{ORG} / \mathrm{kg}$ diet. The levels of all antioxidant enzymes and TAC significantly decreased in control and fish supplemented with $14 \mathrm{~g} \mathrm{ORG} / \mathrm{kg}$ diet. The AChE activity significantly declined in control and fish supplemented with 2 and $14 \mathrm{~g} \mathrm{ORG/kg} \mathrm{diet.}$ After exposure to diazinon, the levels of MDA in liver increased in control and those fed 2 and $14 \mathrm{~g} \mathrm{ORG/kg} \mathrm{diet.} \mathrm{In} \mathrm{fish} \mathrm{supplemented} \mathrm{with} 6$ and $10 \mathrm{~g} \mathrm{ORG/kg} \mathrm{diet,} \mathrm{the}$ MDA levels showed no significant alternations during the experiment period. The serum levels of AST, ALT, and alkaline phosphatase (ALP) elevated during exposure to diazinon in control and fish supplemented with 2 and $14 \mathrm{~g} \mathrm{ORG} / \mathrm{kg}$ diet, while these enzymes showed no significant changes in fish fed with 6 and $10 \mathrm{~g} \mathrm{ORG} / \mathrm{kg}$ diet. Authors concluded that ORG at optimum dietary levels (6 and $10 \mathrm{~g} \mathrm{ORG} / \mathrm{kg}$ diet) could moderate the toxicity induced by diazinon in rainbow trout by enhancing the liver antioxidant system and protecting the hepatocytes. Furthermore, the high dietary levels of ORG caused toxic effects on antioxidant enzymes and hepatocytes, a fact that shows the necessity to optimize its levels in the diet.

Beltrán et al. (2018) evaluated the dietary supplementation with $O$. vulgare extracts in gilthead seabream (Sparus aurata) as a marine fish model due to its importance in aquaculture. The in vitro effects of aqueous and ethanolic leaf extracts of $O$. vulgare were tested in order to observe any immuno-stimulative, cytotoxic, bactericidal or antioxidant properties. The results showed that medium or high concentration of aqueous extracts and low concentrations of ethanolic extract, increased head kidney leucocyte activities as well as the number of SAF-1 cells. However, moderate to high concentrations of ethanolic extracts decreased both leucocyte activities and the number of viable SAF-1 cells, suggesting some possible toxic effects towards them. Only the highest concentration of the aqueous extract and medium to high concentrations of the ethanolic extracts showed cytotoxic activity against the tumor PLHC-1 cell line. Bactericidal activity was only detected against Vibrio harveyi, $V$. anguillarum and Photobacterium damselae when using the highest concentration of aqueous extract and moderate to high concentrations of ethanolic extract. Finally, both plant extracts presented antioxidant activity particularly the aqueous extract. Overall, the results suggest that both extracts (when used at the appropriate concentration) have immuno-stimulative, cytotoxic, bactericidal and antioxidant properties, making $O$. vulgare an interesting candidate for incorporation as additive in functional diets for farmed fish. The main findings associated to the supplementation of oregano essential oil for fish are presented in Table 3. 
Table 3. The main findings associated to the supplementation of oregano essential oil for fish

\begin{tabular}{|c|c|c|c|}
\hline References & Main findings & Studied species & $\begin{array}{l}\text { Components of } \\
\text { oregano basic oil }\end{array}$ \\
\hline Ferreira et al., 2016 & $\begin{array}{l}\text { Increasing absorptive area of the in- } \\
\text { testine } \\
\text { Great deposition of glycogen in the } \\
\text { hepatocytes }\end{array}$ & $\begin{array}{l}\text { Yellow Tail Tetra } \\
\text { fish }\end{array}$ & Oregano oil \\
\hline Yigit et al., 2017 & $\begin{array}{l}\text { Adverse influence of prolonged use } \\
\text { of oregano oil on the liver and kidney }\end{array}$ & Rainbow trout & Oregano oil \\
\hline Rafieepour et al., 2020 & $\begin{array}{l}\text { Improved serum total protein, albu- } \\
\text { min and globulin, respiratory burst } \\
\text { activity, phagocytic activity and se- } \\
\text { rum lysozyme activity }\end{array}$ & Rainbow trout & $\begin{array}{l}\text { Origanum vulgare } \\
\text { extract }(1 \%)\end{array}$ \\
\hline Rafieepour et al., 2020 & $\begin{array}{l}\text { Increased levels of serum thyroxine } \\
\text { (T4) levels and glucose levels (when } \\
\text { fed on } 14 \mathrm{~g} / \mathrm{kg} \text { diet) } \\
\text { Decreased BWI\%, SGR and serum } \\
\text { thyroid hormones in (when fed at } 14 \\
\mathrm{~g} / \mathrm{kg} \text { diet) } \\
\text { FCR decreased in fish fed } 6 \text { and } 10 \mathrm{~g} \\
\text { Cortisol significantly elevated when } \\
\text { fish fed on } 2,14 \mathrm{~g} / \mathrm{kg} \text { diet }\end{array}$ & Rainbow trout & $\begin{array}{l}\text { Origanum vulgare } \\
\text { extract } \\
(6,10,14 \mathrm{~g} / \mathrm{kg} \text { diet })\end{array}$ \\
\hline Rafieepour et al., 2019 & $\begin{array}{l}\text { Total antioxidant capacity (TAC) and } \\
\text { antioxidant enzymes increased (when } \\
\text { fed on } 6,10 \mathrm{~g} / \mathrm{kg} \text { diet) } \\
\text { The hepatic antioxidant enzymes de- } \\
\text { creased when fish fed on } 14 \mathrm{~g} / \mathrm{kg} \text { diet } \\
\text { Hepatic metabolic enzymes, acetyl- } \\
\text { cholinesterase activity and malondi- } \\
\text { aldehyde were not affected }\end{array}$ & Rainbow trout & $\begin{array}{l}\text { Origanum vulgare } \\
\text { extract } \\
(6,10,14 \mathrm{~g} / \mathrm{kg} \text { diet })\end{array}$ \\
\hline Beltrán et al., 2018 & $\begin{array}{l}\text { Potent immunostimulant, cytotoxic, } \\
\text { bactericidal and antioxidant proper- } \\
\text { ties }\end{array}$ & $\begin{array}{l}\text { Gilthead sea- } \\
\text { bream }\end{array}$ & $\begin{array}{l}\text { Origanum vulgare } \\
\text { extract }\end{array}$ \\
\hline
\end{tabular}

\section{Conclusion}

Oregano is a worldwide herb that is extensively used due to its medicinal activities against respiratory, digestive and urinary disorders in addition to dental caries and rheumatoid arthritis. The aforementioned literature and its properties confirmed that that Origanum vulgare feed additive can be used as natural growth promoters (non-antibiotic type). Before the use of natural growth promoters, detailed information about the composition, effectiveness, toxicity and residual analysis must be considered. Phytogenic feed additives have antioxidant, antimicrobial, growth promoting and immunostimulant impacts in animals and humans. Additionally, there are significant positive effects of oregano oil on the increasing absorptive area of the fish intestine. 


\section{References}

Abd El-Hack M., Alagawany M., Farag M.R., Tiwari R., Karthik K., Dhama K., Zorriehzahra J., A del M. (2016). Beneficial impacts of thymol essential oil on health and production of animals, fish and poultry: A review. J. Ess. Oil Res., 28: 365-382.

A bd El-Hack M.E., S a mak D.H., Noreldin A.E., Arif M., Yaqoob H.S., Swelum A.A. (2018). Towards saving freshwater: halophytes as unconventional feedstuffs in livestock feed: a review. Env. Sci. Poultry Res., 25: 14397-14406.

Abd E1-Hack M.E., Abdelnour S., Alagawany M., Abdo M., Sakr M.A., Khafag a A.F., M a h g o u b S.A., E 1 n e s r S.S., G e bri e 1 M.G. (2019). Microalgae in modern cancer therapy: Current knowledge. Biomed. Pharmacother., 111: 42-50.

Abdelnour S.A., Sheiha A.M., Taha A.E., Swelum A.A., Alarifi S., Alkahtani S., Ali D., A 1 B a sher G., A 1 m e e r R., F a lo d a h F., A $1 \mathrm{~m}$ u t a ir i B. (2019). Impacts of enriching growing rabbit diets with Chlorella vulgaris microalgae on growth, blood variables, carcass traits, immunological and antioxidant indices. Animals, 9: 2076-2615.

Adams A., Kumar S., Claus on M., Sahi S. (2011). Anti-yeast activities of Origanum oil against human pathogenic yeasts. Adv. Biosci. Biotechnol., 2: 103.

Ait M'barek L., Ait Mouse H., Ja^afari A., Aboufatima R., Benharref A., Kamal M., Bénard J., El Abbadi N., B ensalah M., Gamouh A., Chait A., Dalal A., Z y a d A. (2007). Cytotoxic effect of essential oil of thyme (Thymus broussonettii) on the IGR-OV1 tumor cells resistant to chemotherapy. Braz. J. Med. Biol. Re., 40: 1537-1544.

A 1 ag aw any M., A b d E 1 - H a ck M.E., F a rag M.R., Tiw a r i R., D ha ma K. (2015). Biological effects and modes of action of carvacrol in animal and poultry production and health. A Review. Adv. Anim. Vet. Sci., 3: 73-84.

A 1 a g a w a n y M., A b d E 1 - H a c k M.E., F a rag M.R., S hah e en H.M., A b d e l - L a t if M.A., Noreldin A.E., Patra A.K. (2018). The usefulness of oregano and its derivatives in poultry nutrition. World's Poult. Sci. J., 74: 463-474.

A 1 a g a w a n y M., A b d E 1 - H a c k M.E., S a e e d M. (2020). Nutritional applications and beneficial health applications of green tea and L-theanine in some animal species: A review. J. Anim. Physiol. Anim. Nutr., 104: 245-256.

A 1 - K a la ld e h J.Z., A b u - D a h a b R., A fi fi F.U. (2010). Volatile oil composition and antiproliferative activity of Laurus nobilis, Origanum syriacum, Origanum vulgare, and Salvia triloba against human breast adenocarcinoma cells. Nut. Res., 30: 271-278.

A 1 - K u s h i A.G. (2014). The effect of aqueous extract of Origanum vulgare Linn on the development of genital ridge in the embryonic stages of rabbit. Int. J. Pure Appl. Sci. Technol., 20: 101.

A rami S., A h m a di A., Ha e ri S.A. (2013). The radioprotective effects of Origanum vulgare extract against genotoxicity induced by $131 \mathrm{I}$ in human blood lymphocyte. Cancer Biother. Radio., 28: 201-206.

Arif M., Hay at Z., Abd El-Hack M.E., Saeed M., Imran H.M., A low a imer A.N., S a d e ld in I.M., Tah a A.E., Sw e lu m A.A. (2019). Impacts of supplementing broiler diets with a powder mixture of black cumin, Moringa and chicory seeds. S. Afr. J. Anim. Sci., 49: 564-572.

Ay u d thay a S.P.N., Van De We ij e r A.H., Van Gelder A.H., S tam s A.J., D e Vos W.M., Plugge C.M. (2018). Organic acid production from potato starch waste fermentation by rumen microbial communities from Dutch and Thai dairy cows. Biotechnol. Biofuels., 11:13.

B a j p a i V.K., B a e k K-H., K a n g S.C. (2012). Control of Salmonella in foods by using essential oils: A review. Food Res. Int., 45: 722-734.

Bampidis V., Christodoulou V., Florou-Paneri P., Christaki E. (2006). Effect of dried oregano leaves versus neomycin in treating newborn calves with colibacillosis. Transbound. Emerg. Dis., 53: 154-156.

B e l trán J.M.G., Es p in o s a C., Guardiola F.A., E s t e b a n M.Á. (2018). In vitro effects of Origanum vulgare leaf extracts on gilthead seabream (Sparus aurata L.) leucocytes, cytotoxic, bactericidal and antioxidant activities. Fish Shellfish Immunol., 79: 1-10.

B e n cha a C., Greathe ad H. (2011). Essential oils and opportunities to mitigate enteric methane emissions from ruminants. Anim. Feed Sci. Technol., 166: 338-355. 
B h a t t a R. (2015). Reducing enteric methane emission using plant secondary metabolites. In: Climate change impact on livestock: Adaptation and Mitigation, Springer, 273-284.

B ir i c i k H., Oral H.H., Taluğ A.M., C engiz Ş.Ş., K o y unc u M., Dikmen S. (2016). The effects of carvacrol and/or thymol on the performance, blood and rumen parameters, and carcass traits of Merino sheep. Turk. J. Vet. Anim. Sci., 40: 651-659.

Bukovská A., Ciko š Š., Juhás Š., Il'ková G., Rehák P., Koppel J. (2007). Effects of a combination of thyme and oregano essential oils on TNBS-induced colitis in mice. Mediators Inflamm., 2007: 23296. doi: 10.1155/2007/23296.

C a r m o E.S., L i m a E.D.O., S o u z a E.L.D. (2008). The potential of Origanum vulgare L. (Lamiaceae) essential oil in inhibiting the growth of some food-related Aspergillus species. Braz. J. Microbiol., 39: 362-367.

Ch a d h a ry P.P., Go e 1 N., B a ker G., S a x en a J., S ingh N., Chaturved i I., Sharma A., Ku mar S irohi S. (2016). Influence of essential oils supplementation on rumen fermentation profile and ruminal microbial population in vitro. J. Sci., 1: 25-34.

Cho B.W., Ch a C.N., L e e S.M., K i m M.J., P ark J.Y., Y o o C.Y., S o n S.E., K i m S., L e e H.J. (2015). Therapeutic effect of oregano essential oil on subclinical bovine mastitis caused by Staphylococcus aureus and Escherichia coli. Kor. J. Vet. Res., 55: 253-257.

Chou T.H., Ding H.Y., Lin R.J., Li ang J.Y., Li ang C.H. (2010). Inhibition of melanogenesis and oxidation by protocatechuic acid from Origanum wulgare (Oregano). J. Nat. Prod., 73: 1767-1774.

Chu n S.S., Vat t e m D.A., L in Y.T., S h e t t y K. (2005). Phenolic antioxidants from clonal oregano (Origanum vulgare) with antimicrobial activity against Helicobacter pylori. Process. Biochem., 40: 809-816.

Cobellis G., Trabalza-Marinucci M., Yu Z. (2016). Critical evaluation of essential oils as rumen modifiers in ruminant nutrition: A review. Sci. Total. Environ., 545: 556-568.

Coc c i m i g li o J., A li p o ur M., Ji ang Z.-H., Got t ard o C., S untres Z. (2016). Antioxidant, antibacterial, and cytotoxic activities of the ethanolic Origanum vulgare extract and its major constituents. Oxid. Med. Cell Longev., 2016: 1404505, doi: 10.1155/2016/1404505.

Coskun S., G iris gin O., Kürkcü oglu M., Malyer H., Girisg in A.O., K 1 r 1 mer N., B a s e r K.H. (2008). Acaricidal efficacy of Origanum onites L. essential oil against Rhipicephalus turanicus (Ixodidae). Parasitol. Res., 103: 259-261.

Dham a K., Karthik K., Khandia R., Munjal A., Tiwari R., Rana R., Khurana S.K., Sana Ullah, Khan R.U., A lagawany M., Farag M.R., Dadar M., Joshi S.K. (2018). Medicinal and therapeutic potential of herbs and plant metabolites/extracts countering viral pathogens - current knowledge and future prospects. Curr. Drug Metab., 19: 236-263.

Dudko P., Junkuszew A., Bojar W., Milerski M., Szczepaniak K., Le Scouarnec J., S chmidová J., Tom c zuk K. Grzybek M. (2017). Effect of dietary supplementation with preparation comprising the blend of essential oil from Origanum vulgare (Lamiaceae) and Citrus spp. (Citraceae) on coccidia invasion and lamb growth. It. J. Anim. Sci., 17: 1-9.

Es en G., Azaz A. D., Kurkcuoglu M., Husnu K., Bas er C., T in maz A. (2007). Essential oil and antimicrobial activity of wild and cultivated Origanum vulgare L. subsp. hirtum (link) letswaart from the Marmara region Turkey. Flav. Fragr. J., 22: 371-376.

Esper R.H., Gonçalez E., Marques M.O., Felicio R.C., Felicio J.D. (2014). Potential of essential oils for protection of grains contaminated by aflatoxin produced by Aspergillus flavus. Front. Microbiol., 5: 269.

F a r a M.R., A 1 a g a w a n y M. (2019). The role of Astragalus membranaceus as immunomodulator in poultry. World. Poult. Sci. J., 75: 43-54.

F erreira P.M., Caldas D.W., S a laro A.L., S artori S.S., Oliveira J.M., C ardos o A.J., $\mathrm{Z} u$ a $n$ on J.A. (2016). Intestinal and liver morphometry of the Yellow Tail Tetra (Astyanax altiparanae) fed with oregano oil. An. Acad. Bras. Cienc., 88: 911-922.

Gu o Y.S., Wang G.C., Wan g C.H., H u a n g X.J., L i Y.L., Ye W.C. (2012). Chemical constituents from Origanum vulgare. Chin. Pharmaceut. J., 47: 109-113.

Habibi E., Shokrzadeh M., Chabra A., Naghshvar F., Keshavarz-Maleki R., A hmadi A. (2015 a) Protective effects of Origanum vulgare ethanol extract against cyclophosphamide-induced liver toxicity in mice. Pharm. Biol., 53: 10-15 
Habibi E., Shokrzadeh M., Chabra A., Naghshvar F., Keshavarz-Maleki R., Ahmad A. (2015 b). Protective effects of Origanum vulgare ethanol extract against cyclophosphamide-induced liver toxicity in mice. Pharm. Biol., 53: 10-15.

H a m m e r K.A., Cars on C., Riley T. (1999). Antimicrobial activity of essential oils and other plant extracts. J. Appl. Microbiol., 86: 985-990.

H a n X., P a r k e r T.L. (2017). Anti-inflammatory, tissue remodeling, immunomodulatory, and anticancer activities of oregano (Origanum vulgare) essential oil in a human skin disease model. Biochim. Open, 4: 73-77.

H a s a n B.F., Khudair A.N., A 1 ka lby J.M. (2016). Study the effects of treating experimental vaginal candidiasis with thyme, oregano oil and nystatin on pituitary-gonadal axis in female rabbits. Bas. J. Vet. Res., 15: 300-320.

Hristov A., L e e C., C a s s idy T., He y ler K., Tekippe J., Varga G., Corl B., B randt R. (2013). Effect of Origanum vulgare L. leaves on rumen fermentation, production, and milk fatty acid composition in lactating dairy cows. J. Dairy Sci., 96: 1189-1202.

H u lá n k o vá R., B oř i l o vá G. (2012). In vitro combined effect of oregano essential oil and caprylic acid against Salmonella serovars, Escherichia coli O157: H7, Staphylococcus aureus and Listeria monocytogenes. Acta Vet. Brno., 80: 343-348.

Hy ldga a rd M., Mygind T., Meyer R.L. (2012). Essential oils in food preservation: mode of action, synergies, and interactions with food matrix components. Front. Microbiol., 3: 12.

K a ra k a y a S., El S.N., K a r a gö zlü N., S a h in S. (2011). Antioxidant and antimicrobial activities of essential oils obtained from oregano (Origanum vulgare ssp. hirtum) by using different extraction methods. J. Med. Food, 14: 645-652.

Kat s oulos P.D., Karatzi a M.A., Dovas C.I., Filious s is G., P a p a dopoulos E., Ki os sis E., Arsenopoulos K., Papadopoulos T., Boscos C., Karatzias H. (2017). Evaluation of the in-field efficacy of oregano essential oil administration on the control of neonatal diarrhea syndrome in calves. Res. Vet. Sci., 115: 478-483.

K hafag a A.F., B ay ad A. (2016 a). Impact of Ginkgo biloba extract on reproductive toxicity induced by single or repeated injection of cisplatin in adult male rats. Int. J. Pharmacol., 12: 340-350.

K h a fa g a A.F., B a y a d A. (2016 b). Ginkgo biloba extract attenuates hematological disorders, oxidative stress and nephrotoxicity induced by single or repeated injection cycles of cisplatin in rats: physiological and pathological studies. Asian J. Anim. Sci., 10: 235-246.

Kolling G.J., P a na z z o lo D.M., G a b b i A.M., S t u m p f M.T., P a s s o s M.B., d a Cruz E.A., $\mathrm{F}$ i s c h e r V. (2016). Oregano extract added into the diet of dairy heifers changes feeding behavior and concentrate intake. Sci. World J., 8917817: 6.

Kris han G., N a r ang A. (2014). Use of essential oils in poultry nutrition: A new approach. J. Adv. Vet. Anim. Res., 1: 156-162.

Kubatka P., Ke 11 o M., Kajo K., Kruzliak P., Výbohová D., Mojžiš J., A da mkov M., F i a lová S., Ve i z e r ová L., Z u 11 i A. (2017). Oregano demonstrates distinct tumour-suppressive effects in the breast carcinoma model. Europ. J. Nutr., 56: 1303-1316.

Kurekci C., Padmanabha J., B ishop-Hurley S.L., Hassan E., Al Jas sim R.A., M c S w e e n e y C.S. (2013). Antimicrobial activity of essential oils and five terpenoid compounds against Campylobacter jejuni in pure and mixed culture experiments. Int. J. Food Microbiol., 166: $450-457$.

L a c erda E., B a u er L., Oliveira J., Silva F., Carvalho S., M a cedo M., d e Souza N., $\mathrm{S}$ i $\mathrm{m}$ i o n a t o J. (2014). Effect of the dietary inclusion of dried oregano (Origanum vulgare L.) on the characteristics of milk from Holstein $\times$ Zebu cows. Anim. Feed Sci. Technol., 192: 101-105.

Li H.Z., Nakashima T., Tanaka T., Zhang Y.J., Yang C.R., Kouno I. (2008). Two new maltol glycosides and cyanogenic glycosides from Elsholtzia rugulosa Hemsl. J. Nat. Med., 62: 75-78.

Liang C.H., Chan L.P., Ding H.Y., So E.C., Lin R.J., Wang H.M., Chen Y., Chou T. (2012). Free radical scavenging activity of 4-(3,4-Dihydroxybenzoyloxymethyl)phenyl-O-bD-glucopyranoside from Origanum vulgare and its protection against oxidative damage. J. Agric. Food Chem., 60: 7690-7696.

Li ang W.Z., L u C.H. (2012). Carvacrol-induced $\left[\mathrm{Ca}^{2+}\right]_{i}$ rise and apoptosis in human glioblastoma cells. Life Sci., 90: 703-711. 
L 1 a n a - R u i z - C a be 11 o M., M a is a n a b a S.,P u er to M.,P i c hardo S., J os A., M o y a no R., C a m é n A. (2017). A subchronic 90-day oral toxicity study of Origanum vulgare essential oil in rats. Food Chem. Toxicol., 101: 36-47.

Manohar V., Ingra m C., Gra y J., Talpur N.A., E chard B.W., B a g c hi D., Preus s H.G. (2001). Antifungal activities of origanum oil against Candida albicans. Mol. Cell. Biochem., 228: $111-117$

Moghaddam M.G., Ansari I., Roghani M., Moradi M. (2013). The effects of Origanum majorana on oxidative stress and histopathology of renal tissue among streptozotocin-induced diabetic rats. Thrita, 2: 29-34.

Mohamed L.A., E1-Hindawy M.M., Alagawany M., Salah A.S., E1-Sayed S.A. (2019). Effect of low- or high-CP diet with cold-pressed oil supplementation on growth, immunity and antioxidant indices of growing quail. J. Anim. Physiol. Anim. Nutr., 2019: 1-8.

Mohamed N.E. (2017). Protective effect of origanum oil on alterations of some trace elements and antioxidant levels induced by mercuric chloride in male rats. Biol. Trace Elem. Res., 182: 49-56.

$\mathrm{Nak}$ a t a n i N., Ki k u zaki H. (1987). A new antioxidative glucoside isolated from Oregano (Origanum vulgare L.). Agr. Biol. Chem., 51: 2727-2732.

N e w m a n D.J., C r a g g G.M. (2007). Natural products as sources of new drugs over the last 25 years. J. Nat. Prod., 70: 461-477.

O h J., H r i s t o v A. (2016). Effects of plant-derived bio-active compounds on rumen fermentation, nutrient utilization, immune response, and productivity of ruminant animals. Medicinal and Aromatic Crops: Production, Phytochemistry, and Utilization. ACS Publications, pp. 167-186.

P a r a s k e va k is N. (2015). Effects of dietary dried Greek Oregano (Origanum vulgare ssp. hirtum) supplementation on blood and milk enzymatic antioxidant indices, on milk total antioxidant capacity and on productivity in goats. Anim. Feed Sci. Technol., 209: 90-97.

P a r a s k e va k is N. (2017). Effects of dietary Greek oregano (Origanum vulgare ssp. hirtum) supplementation on rumen fermentation, enzyme profile and microbial communities in goats. J. Anim. Physiol. Anim. Nutr., 102: 701-705.

P atra A.K. (2011). Effects of essential oils on rumen fermentation, microbial ecology and ruminant production. Asian J. Anim. Vet. Adv., 6: 416-428.

Pensel P., Maggiore M., Gende L., Eguaras M., Denegri M., Elis sondo M. (2014). Efficacy of essential oils of Thymus vulgaris and Origanum vulgare on Echinococcus granulosus. Interdiscip. Perspect. Infect. Dis., 2014:693289.

P e te r K.V. (2004). Growth habit of wild oregano populations. In: Handbook of herbs and spices. 2. Woodhead Publishing.

Rafie e pour A., Hajirezaee S., Rahimi R. (2019). Dietary oregano extract (Origanum vulgare L.) enhances the antioxidant defence in rainbow trout, Oncorhynchus mykiss against toxicity induced by organophosphorus pesticide, diazinon. Toxin Rev., 1-11.

R a fi e e pour A., Hajir e za e e S., R a him i R. (2020). Moderating effects of dietary oregano extract (Origanum vulgare) on the toxicity induced by organophosphate pesticide, diazinon in rainbow trout, Oncorhynchus mykiss: metabolic hormones, histology and growth parameters. Turk. J. Fish Aquat. Sci., 20: 207-219.

R o bu T., Mili că C. (2004). Editor. Plante medicinale autohtone. Institutul European, 324 pp.

Roofchaee A., Irani M., Ebrahimzadeh M.A., Akbari M.R. (2011). Effect of dietary oregano (Origanum vulgare L.) essential oil on growth performance, cecal microflora and serum antioxidant activity of broiler chickens. African J. Biotechnol., 10: 6177-6183.

Salime i P.S., Marfe G., Di Renzo L., Di Stefano C., Giganti M.G. (2007). The interference of rosmarinic acid in the DNA fragmentation induced by osmotic shock. Front. Biosci., 12: $1308-1317$.

S ankar R., Karthik A., Prabu A., Karthik S., Shivashangari K.S., Ravikumar V. (2013). Origanum vulgare mediated biosynthesis of silver nanoparticles for its antibacterial and anticancer activity. Colloids Surf. B Biointerfaces, 108: 80-84.

S a n k a r R., Dhivy a R., S hiv a s hangari K.S., R a vi k u m a r V. (2014). Wound healing activity of Origanum vulgare engineered titanium dioxide nanoparticles in Wistar Albino rats. J. Mat. Sci. Mat. Med., 25: 1701-1708. 
Savin i I., Arn on e R., C a t a n i M.V., Avi g li a n o L. (2009). Origanum vulgare induces apoptosis in human colon cancer Caco2 cells. Nutr. Cancer, 61: 381-389.

Saxena M., Saxena J., Pradhan A. (2012). Flavonoids and phenolic acids as antioxidants in plants and human health. Int. J. Pharmac. Sci. Rev. Res., 16: 130-134.

S ej i a n V., S a mal L., H a que N., B a gat h M., Hy de r I., Ma u rya V., B hat t a R., R avin d r a J., Pra s a d C.S., L a 1 R. (2015). Overview on adaptation, mitigation and amelioration strategies to improve livestock production under the changing climatic scenario. Climate Change Impact on Livestock: Adaptation and Mitigation. Springer, pp. 359-397.

Ş e n H.S., Ş en V., B o z kur t M., T ürk çü G., Güz e l A., S e z g i C., A b a kay Ö., K a plan I. (2014). Carvacrol and pomegranate extract in treating methotrexate-induced lung oxidative injury in rats. Medical Science Monitor. Int. Med. J. Exp. Clin. Res., 20: 1983.

Sheibani V., Hajializadeh Z., A farinesh M. (2010). Evaluation of Origanum vulgare L. ssp. viridis leaves extract effect on discrimination learning and LTP induction in the CA1 region of the rat hippocampus. Iran J. Basic Med. Sci., 14: 161-169.

Sh ew it a R.S., Tah a A.E. (2018). Influence of dietary supplementation of ginger powder at different levels on growth performance, haematological profiles, slaughter traits and gut morphometry of broiler chickens. South African J. Anim. Sci., 48: 997-1008.

Shokrzadeh M., Ahmadi A., Chabra A., Naghshvar F., Salehi F., Habibi E., Hag hi-A minjan H. (2014). An ethanol extract of Origanum vulgare attenuates cyclophosphamide-induced pulmonary injury and oxidative lung damage in mice. Pharm. Biol., 52: 1229-1236.

Sikander M., Malik S., Parveen K., A hmad M., Yadav D., Ha feez Z.B., Bans al M. (2013). Hepatoprotective effect of Origanum vulgare in Wistar rats against carbon tetrachlorideinduced hepatotoxicity. Protoplasma, 250: 483-493.

Soković M., G la močlija J., M arin P.D., Brkić D. van Griens ven L.J. (2010). Antibacterial effects of the essential oils of commonly consumed medicinal herbs using an in vitro model. Molecules, 15: 7532-7546.

S o li man M.M., N a s s a M.A., I s ma il T.A. (2016). Origanum majoranum extract modulates gene expression, hepatic and renal changes in a rat model of type 2 diabetes. Iran. J. Pharm. Res., 15: 45 .

S or e n N., S e j i a n V., M a lik P. (2015). Enteric methane emission under different feeding systems. Climate Change Impact on Livestock: Adaptation and Mitigation. Springer, pp. 187-208.

Srihari T., S eng o t tuve lan M., N a l in i N. (2008). Dose-dependent effect of oregano (Origanum vulgare L.) on lipid peroxidation and antioxidant status in 1, 2-dimethylhydrazine-induced rat colon carcinogenesis. J. Pharm. Pharmacol., 60: 787-794.

Suntres Z.E., Coc c i miglio J., A li p our M. (2015). The bioactivity and toxicological actions of carvacrol. Crit. Rev. Food Sci. Nutr., 55: 304-318.

Tabari M.A., Yous s efi M.R., Maggi F., B e nelli G. (2017). Toxic and repellent activity of selected monoterpenoids (thymol, carvacrol and linalool) against the castor bean tick, Ixodes ricinus (Acari: Ixodidae). Vet. Parasitol., 245: 86-91.

T a h a A.E., H a s s a n S.S., S h e w i t a R.S., E1 - s e i d y A.A., E 1 - H a c k M.E.A., H u s s e in E.S.O., S a d e ld in I.M., Sw e lu m A.A., El-Ed el M.A. (2019). Effects of supplementing broiler diets with coriander seed powder on growth performance, blood haematology, ileum microflora and economic efficiency. J. Anim. Physiol. Anim. Nut., 102: 1625-1633.

Tekippe J., Hristov A., Heyler K., Cassidy T., Zheljazkov V., Ferreira J., Kar$\mathrm{n}$ at i S., Varga G. (2011). Rumen fermentation and production effects of Origanum vulgare L. leaves in lactating dairy cows. J. Dairy Sci., 94: 5065-5079.

Ton g n u a n ch a n P., B e n j a k u l S. (2014). Essential oils: extraction, bioactivities, and their uses for food preservation. J. Food Sci., 79: 1231-1249.

Vujicic M., Nikolic I., Kontogianni V.G., Saksida T., Charisiadis P., Orescanin-Dusic Z., Blagojevic D., Stosic-Grujicic S., Tzakos A.G., Stojanov i c I. (2015). Methanolic extract of Origanum vulgare ameliorates type 1 diabetes through antioxidant, anti-inflammatory and anti-apoptotic activity. Brit. J. Nut., 113: 770-782.

Vujicic M., Nikolic I., Kontogianni V.G., Saksida T., Charisiadis P., Vasic B., Stosic-Grujicic S., Gerothan as s is I.P., Tzakos A.G., S toj anovic I. (2016). Eth- 
yl acetate extract of Origanum vulgare L. ssp. hirtum prevents streptozotocin-induced diabetes in C57BL/6 mice. J. Food Sci., 81: 1846-1853.

Wat a nabe Y., S uzuki R., Ko i ke S., Nagas him a K., Mochizuki M., Forster R., Kob a y a s i Y. (2010). In vitro evaluation of cashew nut shell liquid as a methane-inhibiting and propionate-enhancing agent for ruminants. J. Dairy Sci., 93: 5258-5267.

W u X.J., S ong J.X., Z h a o A.H., J i a W. (2011). Phenolic acid constituents from Dracocephalum moldavica. Nat. Prod. Res. Dev., 23: 446-448.

X i e J.B., L i P. (2002). Studies on phenolic acids from Ilex purpurea Hassk. J. China Pharm. Univ., 33: 76-77.

Yad e ghari S., M a le c k y M., Z a m a n i P., D e h g h a n - B a n a d a k y M. (2013). In vitro evaluation of the effects of Lavandula officinalis and Origanum vulgare essential oils on ruminal fermentation using concentrate and roughage type substrates. J. Livest. Sci. Technol., 1: 1-12.

Y i g it N.O., D il e r O., K o c a S.B., G ormez O. (2017). Effect on histology and nutrient digestibility of supplemented origanum onites essential oil to rainbow trout diets (Oncorhynchus mykiss). Indian J. Pharm. Educ. Res., 51: S262-S267.

Zhang L.H., F ang C.L., Ye W.C. (2008). Study on flavonoids and phenolic acids from the herb of Lygodium japonicum. J. Chinese Med. Mat., 31: 224-226.

Zia r i S.B., Naji T., S a hafi H.H. (2015). Comparison of the effects of Origanum vulgare with LHRH-A 2 and 17 $\beta$-estradiol on the ultrastructure of gonadotroph cells and ovarian oogenesis in immature Trichogaster trichopterus. Anim. Reprod. Sci., 161: 32-39.

Received: 7 VI 2019

Accepted: 13 XII 2019 